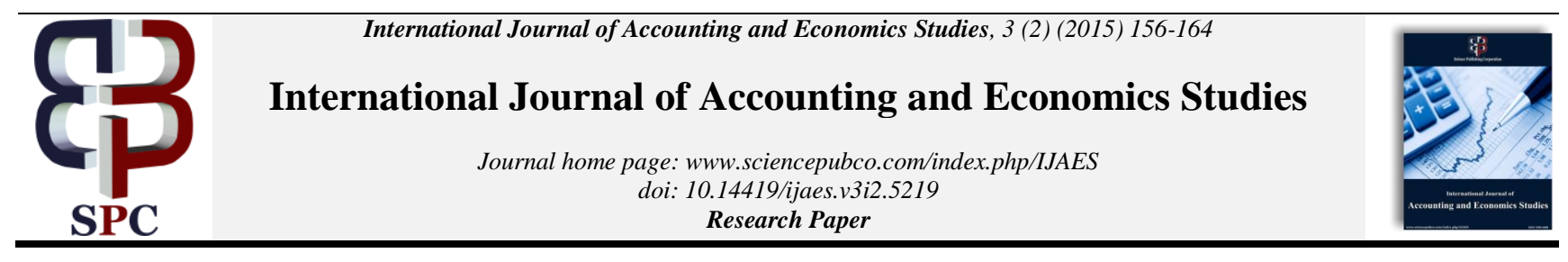

\title{
Clients' selection of auditors: evidence from the Athens stock exchange
}

\author{
Anastasia Maggina \\ Papakostandinou 12, Avlona Attikis 19011, Greece, Business Consultant/Research Scientist \\ E-mail: anastasiamaggina@yahoo.gr
}

\begin{abstract}
The auditing profession is at a crossroad worldwide. It currently faces many challenges especially in Greece where auditor rotation has been instituted as mandatory by EU regulation and the auditing profession is going to be fully liberalized (no limits on audit fees) . Given the Greek environment, it is important to investigate how client companies select auditors. In this study we address three questions. First, can selection of auditors be forecasted? Second, which statistical technique better fits the data set? Third, are there differences in firms' financial ratios as well as institutional factors that affect auditor choice? Clients' selection of auditors is considered in a research context using discriminant analysis and logistic regression. The discriminating factors between the two groups of companies include some firm financial ratios and institutional factors: QATA(Quick Assets/Total Assets) when using one year data, and QATA(Quick Assets/Total Assets) and SHAREHOLD (level of shareholdings) when using two year data. Prediction accuracy is close to 60.0 percent using discriminant analysis and around 80.0 percent using logistic regression. The contribution of this study is that it discriminates between the two groups of companies (Big Four versus second-tier or local auditing firms) in an IFRS environment.
\end{abstract}

Keywords: Selection of Auditors; Clients' Characteristics; IFRS; Discriminant Analysis; Logistic Regression; Prediction

\section{Introduction}

Companies in Greece have been selecting auditors under government oversight for more than a century. However, the financial crisis in Greece has resulted in the full liberalization of the auditing profession and how business enterprises select their auditors. Of particular interest is the fact that auditor rotation has been constituted by EU regulation and the auditing profession was strictly regulated. The regulated auditor selection process was carried out by the General Meeting (General Assembly) of a business enterprise requiring that auditing firms be approached by the company's management. Management then presents the "pros and cons" of the audit firm. After an audit firm is approved during the first selection, a justified proposal is submitted to the General Meeting which makes the choice official. The company can ask for a list of auditors from one or more auditing firms and can make a proposal for one or more auditors along with their alternates. According to the Directive 2006/43/EC (Article 37, Chapter IX-Appointment and Dismissal of Statutory Auditors) "the statutory auditor shall be appointed by the general Meeting of shareholders or members of the audited entity. Member states may allow alternative systems or modalities for the appointment of the statutory auditors or audit firm, provided that those systems or modalities are designed to ensure the independence of the statutory auditor or audit firm from the executive members of the administrative body or from the managerial body of the audited entity."

According to the law in the US, Audit Committees (AC) have the responsibility and authority to hire, terminate or oversee external auditing. In practice the AC confers with management, and shareholders ratify the choice but do not have real power in auditor selection. In 2008, the Department of the Treasury's Advisory Committee on the Auditing Profession recommended that all public companies must have an annual shareholder ratification of the external auditor.

The audit requirement was not imposed in the US until January 1933. According to Benston (1969), in 1926 only 18 percent of NYSE firms were not audited. Company audit in Greece dates back to 1955 with the establishment in that year of the Statecontrolled Body of Sworn-in-Accountants (SOL). The latter in effect performed the roles of both a professional institute and an audit firm which possessed a monopoly over the supply of statutory audit services. The liberalization of the auditing profession in 1992 made the Greek statutory audit market available not only to the Big 6 but also to the second-tier international firms, many of which are members of worldwide networks.

The motivation of the study is related to the low Big 4 market share in Greece compared to other countries. Additional motivation for this study is drawn from the fact that during the transition from domestic accounting standards (DAS) to International Financial Reporting Standards (IFRS) auditors issued only two qualified audit reports (for two large and long established companies and written by second-tier auditors) over the total number of firms listed on the Athens Stock Exchange (ASE) in 2007 and 2008 (286 and 279 companies, respectively). The purpose of this study is threefold. First, to highlight any differences of the two groups of companies as far as some main financial ratios as well as an institutional variable. Second, to determine the prediction accuracy of the selection of auditors. Third, to check which statistical technique better fits the data set. 
This study examines auditor selection in a different context than other studies. We look at auditor selection under the framework of IFRS and, in particular, three years after firms were required to adopt IFRS. In other words, this study takes place in a different business and regulatory environment than other studies. Although IFRS are mandatory for publicly traded companies and optional for all other privately held companies, there is no Enforcement or Oversight Body with an interest in IFRS implementation. This was also evident in the DAS (domestic accounting standards) era when no consistent application was in place resulting in inconsistent accounting information disclosure and observed capital market effects. The Hellenic Accounting and Auditing Oversight Board (ELTE), with its accounting and auditing institutional framework, provide a framework consistent with the accounting and auditing development but in practice it has no authority for the application of IFRS. ELTE is an active member of the European Group of Auditors' Oversight Bodies and as such supports the European concern for auditing development. However, there is a lack of international dimensions both for auditing and IFRS market effects. Operating in this environment, the Greek Government is further liberalizing the auditing profession in the name of greater competition in the profession. The above mentioned weaknesses and the new prospects that will open in the auditing profession make this study special. It lends support for suggestions concerning clients' choices and auditors' enhancements and directions.

This study sheds light on the particular characteristics that distinguish companies that select Big 4 audit firms from those that select second-tier or local auditing firms. Two analytical techniques for a dichotomous response variable have been employed in order to distinguish between the two groups of companies. The explanatory variables used in these techniques are financial and accounting ratios drawn from the ASE. In addition, this study takes place in an accounting environment that transitioned from domestic accounting standards (DAS) to IFRS, that is, from a tax-driven accounting system which was characterized by a stakeholder (debt holder) orientation to a shareholder orientation that is independent of tax-reporting considerations. The fact that only one out of every two executives of Greek-listed companies has an in-depth knowledge of IFRS implies that auditing firms have had to become involved in IFRS training programs for Greek-listed companies during the transition to IFRS (Grant-Thornton, 2006). Brown and Tarca (2005) argue that "the importance of auditors is evidenced by the degree to which auditors are involved in working with their clients, assisting them in learning complex standards, and in setting up their accounting systems so that they may prepare IFRS-compliant financial statements."

In 2008, 17 different auditing firms audited publicly traded companies in Greece (see Appendix I for a listing of these auditing firms). In a time horizon of five years auditing firms hold the following percentages as shown in Table 1:

Based on our final sample of 275 Greek companies for the year 2008, SOL (a local auditing firm, formerly Sworn-in-Auditors) has the greatest market share $(32.73$ percent). Grant Thornton International has 14.55 percent, BDO International 14.55 percent, Price Waterhouse 10.18 percent, Baker Tilly 6.91 percent, Ernst \& Young 5.09 percent, KPMG 4.36 percent, RKF International 3.27 percent, Deloitte Touche 3.27 percent, and the remaining auditing firms less than 1.0 percent. In other words, the Big 4 hold 22.55 percent of the market while SOL holds 32.73 percent. In any year the Big 4 hold a far lower percentage than the market segment in the USA, the UK, and in many continental European countries where the percentage is over 90 percent (Maijoor and Vanstraelen, 2012).

As for the FTSE/ASE 20, 75 percent of the listed companies have audit reports signed by the Big 4 auditing firms. As far as other countries are concerned, the market share of the Big 5 ranges from 5 percent in Finland up to 60.4 percent in Norway.

The factors that discriminate between the use of the Big 4 firms and local/second-tier firms are mainly variables QATA (Quick
Assets/Total Assets) when using one-year data, and QATA (Quick Assets/Total Assets) and SHAREHOLD (when the level of shareholdings is greater than 5 percent) when using two-year data. The first has a negative relationship with clients' selection of auditors while the latter has a positive relationship.

The rest of the paper is organized as follows. Section II presents the evolution of the auditing profession in Greece. Section III presents a review of the literature. Section IV contains the research design. Section V reports empirical findings. Section VI concludes with a summary and suggestions for further future research.

\section{The evolution of the auditing profession in Greece}

The rise of the auditing profession in Greece began immediately after WWII, but became more prominent after the Greek Civil War (1946-1949) when financial and other aid was provided to Greece by the allied governments and many international organizations, particularly the US government (e.g. the Marshal Plan). The need for monitoring management control and distribution of these funds gave prominence to the auditing profession. Because of the important role auditors played in Greece's post war economic recovery, the Greek government established a new regulatory body of auditors, the sworn-in accountants, to oversee and regulate auditors. As a result, a new state-controlled body of sworn-in-accountants was established in 1955, known as SOL (or

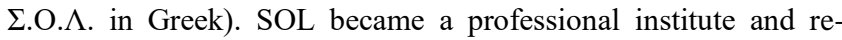
search unit but also functioned as an audit firm (which possessed a monopoly over the supply of statutory audit services) and provided management consulting and other business services.

Companies subject to statutory audits were expected to select an auditor from a list of six SOL auditors provided by the supervisory council of SOL. The audit fee was non-negotiable and was imposed by the supervisory council depending on the duration of the audit. As years passed and contact with auditors from international auditing firms increased, pressure for liberalization of the auditing profession in Greece increased. As a result, in 1979, a rival organization to SOL, the Society of Certified Accountants-Auditors, SELE, was established and won a good share of the auditing market, beginning the liberalization of the profession. As pressure from the European Union grew to move from state-controlled auditors, the issue took political and social dimensions. Finally, in 1992 moving towards liberalization, deregulation and privatization, SOL was abolished with an audit reform law and a new Institute of Certified Auditors (SOE) was established, comprised mainly of former SOL and SELE auditors. It was a radical reform on the supply side of the auditing market brought about by regulatory change. The liberalization of the Greek statutory audit market opened the way for large and small international firms to enter the Greek audit market.

Today in Greece the corporate statutory audit market is shared by five main groups of auditors: (1) big four firms; (2) mid-tier firms (including Grant Thornton and BDO); (3) SOL S.A. (the former governmental organization of certified public accountants); (4) independent local Greek auditors; and (5) small international firms.

The new system, in contrast with regulations predating the 1992 reform, allows appointments of the statutory auditors and the determination of their fees to be freely negotiated between the auditor and client rather than mandated by the government entity. The reform created competition among the audit firms to win and retain audits. As a result, the competition improved the quality of audits and the competence of auditors. Before the reforms, the Greek audit market had all the characteristics of a market operating in a less developed economy. The goal of the reforms is for the 
Table 1: Percent of Companies Audited By Firm Size from 2006-2012

\begin{tabular}{|c|c|c|c|c|c|c|c|}
\hline & 2006 & 2007 & 2008 & 2009 & 2010 & 2011 & 2012 \\
\hline Big Four & 23.47 & 23.02 & 22.22 & 24.26 & 25.19 & 25.22 & 26.60 \\
\hline Mid-tier firms (Grant Thornton and BDO) & 27.97 & 27.92 & 29.03 & 27.21 & 29.77 & 22.23 & 19.70 \\
\hline SOL (Former Sworn-in Auditors) & 29.90 & 32.45 & 32.62 & 30.15 & 28.24 & 25.21 & 25.20 \\
\hline Small Local Firms & 1.29 & 1.13 & 1.43 & 2.57 & 2.29 & 3.00 & 12.40 \\
\hline Small International Firms & 15.43 & 12.83 & 13.98 & 13.97 & 13.36 & 21.37 & 16.05 \\
\hline Joint Audits & 1.93 & 2.64 & 0.72 & 1.84 & 1.53 & 2.99 & 0.45 \\
\hline
\end{tabular}

Greek audit market to operate efficiently and openly, as it does in other developed economies.

\section{Review of the literature}

Most of the prior auditor selection research has focused on quality and the demand and supply of audit services. Regulators and small audit firms allege that audit firm size does not affect audit quality. In contrast, DeAngelo (1981) asserts that audit quality is not independent of audit firm size even when auditors initially possess identical technological capabilities. The larger the auditor, as measured by the number of clients, the less incentive the auditor has to behave opportunistically and the higher the perceived quality of the audit. The quality of audit services has been defined as the market-assessed joint probability that a given auditor will (a) discover a breach in the client's accounting system, and (b) report the breach.

Chow (1982) used an agency theory framework to analyze firms' incentives to hire external auditors. His study postulates that a major reason for firms to hire auditors is to help control the conflict of interests among firm managers, shareholders, and bondholders. Firm characteristics which affect the severity of this conflict or the marginal cost of external auditing are expected to influence a firm's demand for this service. Based on this analysis, leverage, firm size, and the number of accounting-based debt covenants are predicted to increase the probability that a firm will voluntarily hire external auditors. Results suggest that agency costs considerations play an important role in the external auditing decision.

Eichenseher (1985) argues that corporations with substantial foreign assets exhibit a higher propensity to select an identifiable subset of Big 8 auditors than their primarily domestic counterparts. He asserted that if larger CPA firms are more effective monitors of managerial actions because of their enhanced independence, publicly held corporations or, more generally companies with higher debt and non-managerial equity levels, should exhibit greater preferences for large CPA firms. His findings indicate that industry effects in the audit market serve to differentiate not only between large and small CPA firms but also among large CPA firms. The empirical results provide strong support for a relationship between foreign asset positions and domestic auditor selections in the US. In particular, the market positions of two CPA firms (KPMG and PriceWaterhouse) appear more positively affected by foreign holdings by domestic corporations, although other CPA firms also appear to reap foreign advantages in certain industries or locations.

According to Titman and Truman (1986), signaling arguments based on information asymmetries between management and outside investors can be made for quality differences in auditing. They define audit quality as being the level of accuracy of information the auditor supplies to investors. Because users of financial statements cannot directly observe the effectiveness of the audit, they argue that this quality will be inferred from brand name reputation. Such a reputation will be more important and will have more differential impact on investors when potentially large agency costs and informational asymmetries are present.

Simunic and Stein (1987) found only weak support for the management shareholdings hypothesis and counter evidence for the debt-equity hypothesis. Their study showed a significant and negative relationship between the employment of a Big 8 auditor and the debt-equity ratio. Wilson (1988) also found a negative relationship between the debt-equity ratio and the employment of a Big 8 auditor. Ettredge et al. (1988), using a matched-pairs research design, found support for the widely held belief that Big 8 auditors provide a higher quality audit than smaller audit firms.

Firth and Smith (1992) examined the rationale for product differentiation in the market for audits and to test the resulting hypotheses on auditor choice in the new issue market. The product differentiation model argued that different levels of audit quality would be demanded by companies depending on their ownership structure and financial leverage. When agency costs are high, management and underwriters are likely to desire a higher quality audit in order to add more credibility to the financial statements and to the prospectus. The empirical results support the hypothesis of product differentiation in the market for audits, that is, the higher agency costs implied by more managerial shareholdings and high leverage result in or are associated with choosing a Big 8 auditor. Beattie and Fearnley (1995) examined the influences on the auditor choice decision in a country where this decision has not been studied and following a period of rapid and significant environmental upheaval within the auditing profession. They assert that in conceptualising the auditor choice process it is important to recognize that the auditor choice emerges from the client's characteristics, potential auditors' characteristics, and the auditing environment. Their analysis of 29 potentially desirable audit firm characteristics reveals 8 uncorrelated underlying dimensions: reputation/quality, acceptability to third parties, value for money, ability to provide non-audit services, small audit firm, specialist industry knowledge, non-Big 6 large audit firm, and geographical proximity. They posit that auditor choice is motivated by three possible sources: audit environment, audit firm characteristics, and client characteristics.

Caramanis (1998) investigated the impact that the "liberalization" of the Greek auditing profession in 1992 may have had on the behaviour of auditors regarding their performance of various audit functions using a qualitative approach in order to analyze, understand, and explain the perceptions of individual auditors, corporate financial executives, and users of audit reports. The audit reforms of 1992 granted SELE (the "Big 6" auditors) access to the market for statutory audits.

Abbott and Parker (2000) point out that auditor selection is one of the audit committee's primary responsibilities. Using a sample of 500 randomly selected public firms in 11 industry groups, Abbott and Parker estimated whether the likelihood of employing an industry-specialist auditor is related to audit committee characteristics. They provided evidence that industry specialization is an important element of auditor selection. Besides, they predicted that firms with audit committees that are both independent and active are more likely to employ an industry-specialist auditor.

Citron and Manalis (2001) investigated auditor selection in an auditing profession liberalization environment in which the prime driver is not change in client characteristics but a radical reform in the supply side of the market brought about by regulatory change. They investigated which slices of the corporate statutory audit market the international firms gained in the early years of their operation in Greece. Furthermore, their research explored the question whether the brand image of the second-tier firms, as reflected in the company choice of auditor, has more in common with that of the Big 6 firms or with that of the local Greek auditors. A main finding is that company leverage is not associated with auditor selection in post-liberalization Greece. Among other findings is that Big 6 clients are larger, and that there are no significant differences between leverage and ROA levels of the two groups in either year. Findings are consistent with the view that over the period 1993 to 1997, the Big 6 firms made progress, pen- 
etrating the markets for companies in the finance sector, largersized companies, and listed firms. The level of shareholdings by foreign shareholders is positively associated with the choice of a Big 6 versus any other auditor both immediately after the liberalization in 1993 and in 1997. This is evidence that indicates the role of Big 6 firms in providing audit credibility in the eyes of international investors. Another conclusion is that Big 6 firms prioritize the finance sector and large non-finance sector clients in their search for market share. Results are consistent with the view that in post-liberalization Greece companies by their choice of auditor appear to be distinguishing between Big 6 firms and all others but not between second-tier international firms and local auditors. What is in contrast with prior research is that companies that obtained their first listing on the ASE during the period 1993-1997 are not more likely to select Big 6 auditing firms. Another contrast with prior research is that company leverage is not associated with auditor selection in post-liberalization Greece.

Cohen et al. (2009) worked in the environment of the post SOX Act which improved corporate governance in public companies and made the involvement of audit committees mandatory in the selection of auditors. They conducted interviews with 30 experienced audit partners and managers from 3 of the Big 4 firms. They concluded that though many auditors report that management continues to be the dominant player in auditor appointment and dismissal decisions, only about half of the auditors felt audit committees play an important role in resolving auditor disputes with management.

Chan et al. (2006) examined how particular institutional characteristics of heavy government influence on company management and audit firms in China affect auditor opinions. Specifically, they studied whether local auditors who have greater economic dependence on local clients are more likely to report favorably on their local-government clients. Note that listed companies in China are owned primarily by local governments, and the majority of local audit firms was previously affiliated and had close connections with these governments.

Hodgdon et al. (2009) examined the impact of auditor choice on IFRS compliance and their results suggest that compliance is positively related to auditor choice using as explanatory variables the size, profitability, leverage, degree of international diversification, and whether a firm has a US listing or was audited according to International Standards of Auditing. Auditor choice is defined as being audited by a Big-5+2 auditor (the international Big 5 firms plus BDO and Grant Thornton).

Another aspect of auditor selection consideration related to ratification of auditors has been forwarded by many researchers in the USA (Raghunandan (2003); Meyhew and Pike (2004), Krishnan and Ye (2005), Dao, Raghunadan and Rama (2012)). Raghunandan (2003) analyzed shareholder votes at 172 of the Fortune 1000 companies and his results provide empirical support to the SEC's assertion that disclosure of fees paid to the auditor can influence shareholder' voting decisions. Mayhew and Pike (2004) examined potential institutional changes over the control of the hiring and firing of auditors as a way to reduce the proportion of independence violations. They found that instituting auditor selection by investors significantly decreases independence violations, and when combined with eliminating the auditor's moral hazard over effort, almost completely eliminates independence violations. Their results suggest that placing control over the hiring and firing of auditors in the hands of a party separate from client management can substantially improve auditor independence. Krishnan and Ye (2005) using a sample of 383 companies from the S\&P 500 found that the probability that companies ask shareholders to vote on auditor selection is positively associated with the total fees they pay their auditors. In addition, the quality of the audit committee, as measured by financial expertise, has a positive effect on the decision to seek shareholder ratification. Finally, they found that the probability that the company seeks shareholder ratification is negatively associated with the extent of shareholder dissatisfaction with the board, as measured by the votes against directors.

Hypotheses Development
We test primarily for the probability of clients' selection of auditors. The point of interest is how great is this probability and whether the two groups (those that select Big 4 auditing firms and those that select non-Big4 auditing firms) have the same discriminant function scores, which variables make the discrimination between the two groups of companies, and which predictors contribute to the final decision of client firms as far as the auditors selection.

Hypothesis 1: there are significant differences between return on assets in the two groups of companies

Hypothesis 2: there are significant differences between net worth/total debt (or total debt/total assets) in the two groups of companies

Hypothesis 3: the null hypothesis that the two groups have the same mean discriminant function scores

Hypothesis 4: assets size affects the classification accuracy and the prediction rate in the clients' selection of auditors

\section{The research design}

\section{Research Method}

The research methods must address the following questions: Can companies that select Big 4 auditing firms be distinguished from companies that do not select Big 4? How accurately can the two types of firms be classified? Can prediction be appropriately used in decision making? The research method must compare companies that have selected Big 4 auditing firms with companies that have not. Discriminant analysis and logistic regression are appropriate and robust statistical techniques for this purpose. These techniques have been successfully used in many applications to discriminate between groups of companies on the basis of predictor or explanatory variables.

Let $\mathrm{Y}$ be an indicator variable that is 1 if a company selects a Big 4 audit firm and 0 if it does not. Furthermore, let $x=(1, x 1 \ldots x k)$ denote the predictor or explanatory variables. The leading 1 in vector $\mathrm{x}$ allows for an intercept term. In this study, $\mathrm{x} 1 \ldots \mathrm{xk}$ are key financial ratios. The logistic regression model states that the conditional probability $\mathrm{P}(\mathrm{Y}=1 \mid \mathrm{x})$ for a company has the following logistic form:

$\mathrm{P}(\mathrm{Y}=1 \mid \mathrm{x})=\exp (\mathrm{xb}) /[1+\exp (\mathrm{xb})]$

Where notation $x b$ is shorthand for $b 0+b 1 x 1+\ldots+b k x k$. Equation (1) may be rewritten as:

$\ln [\mathrm{P}(\mathrm{Y}=1 \mid \mathrm{x}) / \mathrm{P}(\mathrm{Y}=0 \mid \mathrm{x})]=\mathrm{xb}=\mathrm{b} 0+\mathrm{b} 1 \mathrm{x} 1+\ldots+\mathrm{bkxk}$,

Where $\mathrm{P}(\mathrm{Y}=0 \mid \mathrm{x})=1-\mathrm{P}(\mathrm{Y}=1 \mid \mathrm{x})$

Note in (2) that logistic regression assumes the log-odds of the event is a linear combination of the explanatory variables. The sample data are used to estimate the unknown intercept b0 and regression coefficients $\mathrm{b} 1 \ldots \mathrm{bk}$. The signs and magnitudes of the estimated regression coefficients describe the direction and strength of association between each explanatory variable and the log-odds of Big 4 selection. The estimated regression function also provides, by calculation from equation (1), an estimate of $\mathrm{P}(\mathrm{Y}=1 \mid \mathrm{x})$, the probability that the firm will select one of the Big 4 . The estimates of $\mathrm{P}(\mathrm{Y}=1 \mid \mathrm{x})$ can therefore also be used for classifying (or predicting) the choice of a firm.

Linear discriminant analysis is a statistical method that is closely related to logistic regression. Like logistic regression, it can be used for predicting group membership on the basis of the values of a set of predictor variables. Discriminant analysis generates a discriminant score $\mathrm{d}=\mathrm{x} \mathrm{c}=\mathrm{c} 0+\mathrm{c} 1 \mathrm{x} 1+\ldots+\mathrm{ckxk}$ for each company that is a linear combination of the explanatory variables. The score $d$ can be used to classify companies as Big 4 users or not. The higher the score $\mathrm{d}$ for a company, the more likely the company is to select a Big 4 auditing firm. The score d is used to classify companies as Big 4 users or not according to whether $\mathrm{d}$ is above or 
below a selected cutoff point. Discriminant analysis software estimates the coefficients $\mathrm{c} 0, \mathrm{c} 1, \ldots, \mathrm{ck}$ of the discriminant function and automatically produces a classification Table that shows the success of the explanatory variables as discriminating factors. An exact linear discriminant function arises mathematically if the explanatory variables $\mathrm{x}=(\mathrm{x} 1 \ldots \mathrm{xk})$ have a multivariate normal distribution for each of the two populations corresponding to $\mathrm{Y}=1$ and $\mathrm{Y}=0$. The normal model requires the two populations to share a common covariance matrix. In this situation, the discriminant analysis considers the conditional distribution of the explanatory variables $\mathrm{x}$ given the dependent variable $\mathrm{Y}$. The normal model produces the following classification rule:

Classify the company as

$$
\mathrm{Y}=1 \text { if } \mathrm{P}(\mathrm{x} \mid \mathrm{Y}=0) \mathrm{P}(\mathrm{Y}=0)<\mathrm{P}(\mathrm{x} \mid \mathrm{Y}=1) \mathrm{P}(\mathrm{Y}=1)
$$

Classify the company as $\mathrm{Y}=0$ otherwise,

Which is equivalent to the linear discriminant function just described. The notation $\mathrm{P}(\mathrm{Y}=1)$ in (3) denotes the prior probability that a company will choose one of the Big 4 and $P(x \mid Y=1)$ is the likelihood that a company has explanatory vector $\mathrm{x}$ if it has chosen a Big 4 firm. We assume in this study that the prior probabilities are equal, that is, $\mathrm{P}(\mathrm{Y}=1)=\mathrm{P}(\mathrm{Y}=0)=1 / 2$. Thus the classification rule in (3) simplifies somewhat and depends only on the relative magnitudes of the likelihood values $\mathrm{P}(\mathrm{x} \mid \mathrm{Y}=1)$ and $\mathrm{P}(\mathrm{x} \mid \mathrm{Y}=0)$.

It has been argued on theoretical grounds that discriminant analysis should be used if the explanatory variables are normally distributed. If the explanatory variables are not normally distributed, however, discriminant analysis gives inconsistent estimates, and one is better off using logistic regression analysis (Maddala, 1991). Logistic regression is considered preferable not only for theoretical reasons but also for the particularities of the sample selection. Theoretically, logistic regression is usually preferable to discriminant analysis when one wants to see the contribution of each variable to the differentiation of the groups. It is also effective even when the main objective is classification.

Variables Selection

The variables used are represented by the financial ratios selected in this study. They have been selected in order to have a complete picture of the profile of the company and because they have been employed in other studies (Maggina, 2008). The list of financial ratios used is as follows:

\begin{tabular}{|c|c|c|}
\hline Financial Ratios & Abbreviation & Description \\
\hline $\begin{array}{l}\text { Net Income:Total Assets } \\
\text { (Return on Assets) }\end{array}$ & NITA & $\begin{array}{l}\text { Net Income to Total } \\
\text { Assets }\end{array}$ \\
\hline $\begin{array}{l}\text { Cash:Current Liabilities } \\
\text { (Liquidity Ratio) }\end{array}$ & CASCL & $\begin{array}{l}\text { Cash to Current } \\
\text { Liabilities }\end{array}$ \\
\hline $\begin{array}{l}\text { Cash:Total Assets } \\
\text { (Liquidity Ratio) }\end{array}$ & CASTA & Cash to Total Assets \\
\hline $\begin{array}{l}\text { Quick Assets:Total Assets } \\
\text { (Quick Ratio) }\end{array}$ & QATA & $\begin{array}{l}\text { Quick Assets to } \\
\text { Total Assets }\end{array}$ \\
\hline $\begin{array}{l}\text { Current Assets:Sales } \\
\text { (Return of Current Assets to } \\
\text { Sales) }\end{array}$ & CASA & $\begin{array}{l}\text { Current Assets to } \\
\text { Sales }\end{array}$ \\
\hline $\begin{array}{l}\text { Net Worth:Total Debt } \\
\text { (Equity to Debt Ratio) }\end{array}$ & NWTD & $\begin{array}{l}\text { Net Worth to Total } \\
\text { Debt }\end{array}$ \\
\hline $\begin{array}{l}\text { Receivables:Inventories } \\
\text { (Short-term Financial Ratio) }\end{array}$ & RECINV & $\begin{array}{l}\text { Receivables to In- } \\
\text { ventories }\end{array}$ \\
\hline $\begin{array}{l}\text { Working Capital:Total Assets } \\
\text { (Working Capital Percentage on } \\
\text { Total Assets) }\end{array}$ & WCTA & $\begin{array}{l}\text { Working Capital to } \\
\text { Total Assets }\end{array}$ \\
\hline $\begin{array}{l}\text { Total Debt:Total Assets } \\
\text { (Leverage Ratio) }\end{array}$ & TDTA & $\begin{array}{l}\text { Total Debt to Total } \\
\text { Assets }\end{array}$ \\
\hline $\begin{array}{l}\text { Net Income:Sales } \\
\text { (Return on Sales) }\end{array}$ & NISA & Net Income to Sales \\
\hline $\begin{array}{l}\text { Sales:Working Capital } \\
\text { (Working Capital Turnover) }\end{array}$ & SAWC & $\begin{array}{l}\text { Sales to Working } \\
\text { Capital }\end{array}$ \\
\hline $\begin{array}{l}\text { Percentage of Shareholdings } \\
\text { (More than } 5 \% \text { ) }\end{array}$ & SHAREHOLD & $\begin{array}{l}\text { Level of Sharehold- } \\
\text { ings }\end{array}$ \\
\hline
\end{tabular}

Profitability, liquidity and leverage ratios have been tested and successfully justified as the leading ratios for many corporate (business) events. Large shareholders (more than 5\%) is added to show if large shareholders could be a discriminating variable between companies that select Big 4 auditing firms and companies that select local or second-tier auditing firms. This latter variable has been selected because Dao, Rama and Raghunadan (2012) have found that shareholder voting on auditor selection leads to both higher audit fees and better audit quality with subsequent restatements as a measure of audit quality. Increased shareholder participation is also likely to strengthen auditor independence. Besides, Dao et al. also found that abnormal accruals are lower in firms with shareholder involvement in auditor selection.

The Sample Selection

The sample consists of companies that have reported financial statements and audit reports listed on the web site of the ASE for one or two years before the event of the selection of Big 4 auditing firms, commencing with the most recently published data in 2008 . The total number of firms that reported financial statements published on the Internet is 282 companies for 2008. 275 companies have two consecutive years of data before the event of the selection of Big 4. Companies that have selected Big 4 auditing firms are 62 on the web site of the ASE and in the sample. The rate of companies that have selected Big 4 auditing firms is 21.99 percent over the total population (62 companies over 282 companies that report financial statements) and 22.55 percent for the sample used in this study (62 companies over 275 companies). The sample is dispersed in a wide range of ASE industry codes. This is given in the following Table 2 .

Table 2: ASE Industry and Number of Firms

\begin{tabular}{lc}
\hline Food & 19 \\
\hline Clothes & 18 \\
Banks & 15 \\
Construction & 15 \\
Construction Equipment & 12 \\
Real Estate & 10 \\
Consumer Goods & 10 \\
Computer Services & 10 \\
Publishers & 10 \\
Agriculture and Fishery & 9 \\
Steel & 9 \\
Chemicals & 8 \\
Medical Services & 7 \\
Packing & 7 \\
Travel and Tourism & 6 \\
Investment Companies & 6 \\
Telecommunications and Telecomm. Equipment & 5 \\
Machinery of Industrial Equipment & 5 \\
Clothes and Axesoir & 4 \\
Aluminum & 4 \\
Hotels & 4 \\
Personal Care & 4 \\
Computer Materials & 4 \\
Software & 4 \\
Support Services to Computers & 4 \\
Industry Suppliers & 3 \\
Financial Services & 3 \\
Insurance & 3 \\
TV Entertainment & 3 \\
Bus and Cars & 3 \\
Transport Services & 3 \\
\hline
\end{tabular}

According to the ASE industry classification, only banks (19.4 percent over the total number of companies that have selected Big 4) and real estate companies (9.8 percent) mainly prefer Big 4 auditing firms. Food companies, aluminum companies, and construction equipment companies follow with 4.8 percent. This is evidence that Big 4 may have a specialization in the banking industry but no other industry specialization. The Big 4 market share (62 companies over 275) is dispersed in 33 industry codes.

\section{Empirical findings and discussion}

In a consideration of means of each variable used in the analysis, results are more illustrative of the differences between groups of 
companies. Companies which selected Big 4 auditing firms and those that did not select Big 4 firms do not present great differences, except CASA (Current Assets/Sales), NWTD (Net Worth/Total Debt), RECINV (Receivables/Inventories), and SAWC (Sales/ Working Capital) when data for one year before the event are used. Obviously, this is evidence that those variables will be the most crucial variables in the discriminating process as well as the predictive ability of models employed in this study. When data for two years (one year before and two years before the event) are used means differ between the two groups of companies for variables like CASCL (Cash/Current Liabilities), CASA (Current Assets/Sales), NWTD (Net Worth/Total Debt), RECINV (Receivables/ Inventories), and SAWC (Sales/Working Capital). Hypothesis 1 is accepted which is consistent with prior studies and, in particular, in the post 1992 liberalization era of the Greek audit market. Hypothesis 2 is rejected since when outliers are excluded there are no significant differences in leverage. This is consistent with the above mentioned Greek study (Citron and Manalis, 2001)

Table 3: Average Ratios (Standard Errors) of Predictors

\begin{tabular}{|c|c|c|c|c|}
\hline \multirow[b]{2}{*}{ Measure } & \multirow[b]{2}{*}{ Big 4} & Ill Data & \multicolumn{2}{|c|}{ Outliers Excluded } \\
\hline & & Non Big 4 & Big 4 & Non Big 4 \\
\hline \multicolumn{5}{|c|}{ Panel A: One Year Before } \\
\hline NITA & $\begin{array}{l}0.019 \\
(0.015)\end{array}$ & $\begin{array}{l}-0.026 \\
(0.014)\end{array}$ & $\begin{array}{l}0.008 \\
(0.009)\end{array}$ & $\begin{array}{l}-0.026 \\
(0.014)\end{array}$ \\
\hline \multirow{2}{*}{ CASCL } & 0.712 & 1.103 & 0.610 & 0.300 \\
\hline & $(0.819)$ & $(0.429)$ & $(0.235)$ & $(0.043)$ \\
\hline \multirow{2}{*}{ CASTA } & 0.083 & 0.084 & 0.083 & 0.084 \\
\hline & $(0.015)$ & $(0.001)$ & (1.532) & $(0.010)$ \\
\hline \multirow{2}{*}{ QATA } & 0.402 & 0.435 & 0.402 & 0.435 \\
\hline & $(0.034)$ & $(0.030)$ & $(0.034)$ & $(0.030)$ \\
\hline \multirow{2}{*}{ CASA } & 2.715 & 1.506 & 2.715 & 1.210 \\
\hline & $(0.669)$ & $(0.254)$ & $(0.669)$ & $(0.186)$ \\
\hline \multirow{2}{*}{ NWTD } & 4.969 & 2.538 & 0.958 & 0.968 \\
\hline & (2.632) & $(0.820)$ & $(0.206)$ & $(0.108)$ \\
\hline \multirow{2}{*}{ RECINV } & 5.507 & 122.732 & 2.485 & 4.092 \\
\hline & $(1.925)$ & $(103.052)$ & $(0.452)$ & $(0.335)$ \\
\hline \multirow{2}{*}{ WCTA } & 0.125 & 0.155 & 0.125 & 0.155 \\
\hline & $(0.035)$ & $(0.032)$ & $(0.035)$ & $(0.032)$ \\
\hline \multirow{2}{*}{ TDTA } & 0.618 & 0.643 & 0.618 & 0.643 \\
\hline & $(0.034)$ & $(0.031)$ & $(0.034)$ & $(0.031)$ \\
\hline \multirow{2}{*}{ NISA } & 0.028 & -0.291 & 0.028 & -0.291 \\
\hline & $(0.061)$ & $(0.132)$ & $(0.061)$ & $(0.132)$ \\
\hline \multirow{2}{*}{ SAWC } & 3.557 & -1.950 & 1.768 & 2.215 \\
\hline & (3.137) & (5.345) & $(0.791)$ & $(0.366)$ \\
\hline \multirow{2}{*}{ SHAREHOLD } & 62.888 & 61.745 & 62.888 & 61.745 \\
\hline & $(2.930)$ & (1.397) & $(2.930)$ & (1.397) \\
\hline \multicolumn{5}{|c|}{ Panel B:Two Years Before (one and two) } \\
\hline \multirow{2}{*}{ NITA } & 0.023 & 0.003 & 0.029 & 0.003 \\
\hline & $(0.006)$ & $(0.008)$ & $(0.088)$ & $(0.008)$ \\
\hline \multirow{2}{*}{ CASCL } & 2.393 & 0.991 & 0.573 & 0.363 \\
\hline & (1.055) & $(0.2600$ & $(0.135)$ & $(0.042)$ \\
\hline \multirow{2}{*}{ CASTA } & 0.084 & 0.079 & 0.084 & 0.079 \\
\hline & $(0.011)$ & $(0.006)$ & $(0.011)$ & $(0.061)$ \\
\hline OATA & 0.389 & 0.435 & 0.389 & 0.435 \\
\hline QA1A & $(0.023)$ & $(0.022)$ & $(0.023)$ & $(0.022)$ \\
\hline CASA & 3.232 & 4.826 & 2.497 & 1.332 \\
\hline CASA & $(0.836)$ & $(2.511)$ & $(0.402)$ & $(0.116)$ \\
\hline NWTD & 4.209 & 2.815 & 1.084 & 1.149 \\
\hline NWID & (1.622) & $(0.614)$ & $(0.167)$ & $(0.099)$ \\
\hline RECINV & 4.428 & 118.665 & 2.453 & 3.964 \\
\hline KECIIN & (1.045) & (69.707) & $(0.340)$ & $(0.228)$ \\
\hline WCTA & 0.136 & 0.169 & 0.136 & 0.169 \\
\hline WCIA & $(0.024)$ & $(0.021)$ & $(0.024)$ & $(0.021)$ \\
\hline TDTA & 0.598 & 0.619 & 0.598 & 0.619 \\
\hline IDIA & $(0.024)$ & $(0.023)$ & $(0.024)$ & $(0.023)$ \\
\hline NISA & 0.078 & -0.225 & 0.078 & -0.143 \\
\hline NISA & $(0.035)$ & $(0.115)$ & $(0.035)$ & $(0.080)$ \\
\hline SAWC & 2.351 & 1.565 & 1.248 & 2.052 \\
\hline SAWC & $(1.802)$ & $(2.922)$ & $(0.512)$ & $(0.269)$ \\
\hline SHAREHOLD & 61.991 & 59.928 & 61.991 & 59.928 \\
\hline SНАКЕНULD & (2.193) & $(1.055)$ & $(2.192)$ & $(1.055)$ \\
\hline
\end{tabular}

As in the literature, the quick ratio of companies audited by Big 4 auditing firms is lower than companies audited by non-Big 4 firms (local auditing firms or second-tier firms). Empirical findings are consistent with the literature as far as return on assets is concerned but only with all data (without outliers excluded) and with one year before data. When outliers are excluded and when using two years before data the situation is different. So, as far as Hypothesis 3 results are mixed.

Kolmogorov-Smirnov is an appropriate statistic to test normality. It is very important to test normality because outliers may have a big influence. Outliers have been defined as the extreme values of the variables. Prior studies have shown that non-normally distributed financial ratios are characterized by the presence of outliers. It is worth noting that we have 51 outliers in RECINV and SAWC, 16 in NWTD, 11 in CASCL, and 6 in CASA.

As shown in Table 4, almost all variables are normally distributed, except WCTA (Working Capital/Total Assets), TDTA (Total Debt/Total Assets), and SAWC (Sales/Working Capital) in case of companies that have selected a Big 4 auditing firm. In case of companies that have selected local or second-tier auditing firms, all variables are normally distributed, except SHAREHOLD (level of shareholdings).

The choice of the best fitting model is stressed through a discussion of all empirical findings drawn from a test of discriminant and logit analysis. In each year, a company is observed in one of two alternative states. Coefficients for each model and for each variable in one and two years before the event of the selection of auditors along with the whole data set are given in Table 5 .

Wilk's lamda, one of the various statistics available, is used to test the significance of the discriminant function as a whole. The significant lamda that is shown in Table 5 indicates that Hypothesis 3 (that the two groups have the same mean discriminant function scores) can be rejected, and we conclude that the model is discriminating. In discriminant analysis,almost all variables contribute marginally (see Table 5), except QATA (Quick Assets/Total Assets), and WCTA (Working Capital/Total Assets), which are the most discriminating variables when discriminant analysis is employed with one year data. Using two years data only, QATA is the most discriminating variable. Furthermore,the low eigenvalue means that each variable alone cannot sufficiently explain the model. In discriminant analysis,the significance of the test is strong evidence which leads to the selection of the best statistical technique. When logit is employed,there are different variables that operate as strong discriminating variables. These are QATA (Quick Assets/Total Assets) and SHAREHOLD (level of shareholdings (5\% and more)) and they are about the same when outliers are excluded. Note that the first has a negative relationship with clients' selection of auditors (statistically significant at 0,008 level of significance) while the latter has a positive relationship (statistically significant at 0.075 level of significance). When two years data are used, the most discriminating variables are QATA (Quick Assets/Total Assets) which is statistically significant at 0.000 level of significance and SHAREHOLD(level of shareholdings( 5 percent and more)) which is statistically significant at 0.008 level of significance, and when outliers are excluded the picture does not change significantly.

Once the values of the discriminant coefficients are estimated, it is possible to calculate discriminant scores for each observation in the sample, or any firm, and to assign the observations to one of the groups based on this score. The essence of the procedure is to compare the profile of an individual firm with that of the alternative groupings. In this manner, the firm is assigned to the group it most closely resembles. 
Table 4: Normality Test (Kolmogorov-Smirnov)

\begin{tabular}{|c|c|c|c|c|}
\hline \multirow[b]{2}{*}{ Measure } & \multicolumn{2}{|c|}{ All Data } & \multicolumn{2}{|c|}{ Outliers Excluded } \\
\hline & Big 4 & Non Big 4 & Big 4 & Non Big 4 \\
\hline \multicolumn{5}{|c|}{ Panel A: One Year Before } \\
\hline NITA & $2.217^{* * *}$ & $3.703^{* * *}$ & 0.995 & $3.703^{* * *}$ \\
\hline CASTA & $2.171^{* * * *}$ & $4.101^{* * *}$ & $2.171^{* * *}$ & $4.101^{\text {*** }}$ \\
\hline QATA & $1.481^{* *}$ & $2.726^{* * *}$ & $1.481^{* *}$ & $2.726^{* * *}$ \\
\hline CASA & $2.710^{* * * *}$ & $4.947^{* * *}$ & $2.710^{* * *}$ & $4.466^{* * *}$ \\
\hline RECINV & $2.401^{* * * *}$ & $6.454^{* * *}$ & $1.582^{* *}$ & $3.002^{* * *}$ \\
\hline WCTA & 0.912 & $2.893^{* * *}$ & 0.912 & $2.893^{* * *}$ \\
\hline TDTA & 0.785 & $2.839^{* * *}$ & 0.785 & $2.839^{* * *}$ \\
\hline NISA & $1.995^{* * *}$ & $5.614^{* * *}$ & $1.995^{* * *}$ & $5.614^{* * *}$ \\
\hline SAWC & $2.299^{* * *}$ & $5.937^{* * *}$ & $1.324^{*}$ & $1.558^{* *}$ \\
\hline SHAREHOLD & 1.066 & 1.108 & 1.066 & 1.109 \\
\hline \multicolumn{5}{|c|}{ Panel B:Two Years Before (one and two) } \\
\hline CASCL & $4.670^{* * *}$ & $8.794^{* * *}$ & $3.811^{* * *}$ & $6.864^{\text {*** }}$ \\
\hline CASTA & $3.141^{\text {**** }}$ & $5.458^{* * *}$ & $3.141^{* * *}$ & $5.458^{* * * *}$ \\
\hline QATA & $1.740^{* * *}$ & $3.846^{* * *}$ & $1.740^{* * *}$ & $3.846^{* * *}$ \\
\hline CASA & $3.921^{* * *}$ & $9.327^{* * *}$ & $3.792^{* * *}$ & $5.980^{* * * *}$ \\
\hline NWTD & $4.657^{* * *}$ & $8.452^{* * *}$ & $3.146^{* * *}$ & $5.459^{* * *}$ \\
\hline RECINV & $3.176^{* * *}$ & $9.145^{* * *}$ & $2.353^{* * *}$ & $3.956^{* * *}$ \\
\hline WCTA & 1.080 & $3.944^{* * *}$ & 1.080 & $3.944^{* * *}$ \\
\hline TDTA & 0.853 & $4.256^{* * *}$ & 0.853 & $4.256^{* * *}$ \\
\hline NISA & $2.638^{* * *}$ & $8.412^{* * *}$ & $2.638^{* * *}$ & $8.048^{* * *}$ \\
\hline SAWC & $3.194^{* * *}$ & $7.560^{* * *}$ & $1.947^{* * *}$ & $2.909^{* * * *}$ \\
\hline SHAREHOLD & $1.457^{* *}$ & $1.590^{* *}$ & $1.457^{* *}$ & $1.590^{* *}$ \\
\hline
\end{tabular}

Table 5: Discriminant Analysis and Logit Regression of Auditor Selection All Data Outliers Excluded

$$
\text { Discriminant Logit Discriminant Logit }
$$

Predicted Coeffi. Predicted Coeff. Predicted Coeff. Predicted Coeff.

Sign Sign Sign $\quad$ Sign

Panel A: One Year Before

NITA $+0.043+0.787(0.692)+0.071+0.209(0.921)$

CASC L $+0.216-0.173(0.822)+0.067+0.203(0.825)$

CASTA - $0.201+1.207(0.727)+0.007+1.255(0.782)$

QATA - $1.794-4.271(0.008)+1.530-3.584(0.098)$

CASA - $0.313-0.101(0.500)-0.004-0.015(0.936)$

NWTD - $0.350-0.065(0.669)+0.088-0.047(0.846)$

RECINV - $0.124-0.006(0.461)+0.368-0.070(0.345)$

WCTA $+1.338+1.755(0.152)-1.095+1.311(0.449)$

TDTA $+0.667+1.404(0.225)-0.303+0.479(0.801)$

NISA $-0.072-0.005(0.987)-0.076+0.064(0.824)$

SAWC $+0.187+0.003(0.560)+0.012+0.004(0.904)$

SHAREH $+0.534+0.020(0.075)-0.608+0.025(0.062)$ (P-values are given in parenthesis)
Eigenvalue $=0.064$
Correlation $=0.245 \mathrm{X}^{2}=19.978 \quad$ Correlation $=0.248 \mathrm{X}^{2}=14.084$
Eigenvalue $=0.066$

Wilk's Lamda $=0.940$ Signif. $=0.068$ Wilk's lamda $=0.938$ Signif $=0.295$ 2

$\mathrm{X}^{2}=13.341$ Wald test $=72.745$

Significance $=0.345$

$\mathrm{N}$ of observations:

Total 712

$\mathrm{X}^{2}=10.319$ Wald test $=53.885$

Significance $=0.588$

$\mathrm{N}$ of observations:

Total 711

Valid 223 Selected cases included in the analysis 170

Panel B: Two Years Before (one and two)

\begin{tabular}{|c|c|c|c|c|c|c|c|}
\hline \multicolumn{8}{|c|}{ All Data Outliers Excluded } \\
\hline \multicolumn{8}{|c|}{ Predicted Coeff. Predicted Coeff. Predicted Coeff. Predicted Coeff. } \\
\hline & Sigr & & $\mathrm{Si}$ & & Sign & & Sign \\
\hline NITA & + & 0.023 & + & $0.727(0.660)$ & - & 0.070 & $+.503(0.780)$ \\
\hline CASCL & + & 0.315 & + & $0.005(0.989)$ & - & 0.044 & $-0.063(0.863)$ \\
\hline CASTA & - & 0.085 & + & $0.996(0.688)$ & + & 0030 & $+1.087(0.690)$ \\
\hline QATA & - & 1.719 & - & $4.484(0.000)$ & - & 0.109 & $-3.668(0.017)$ \\
\hline CASA & - & 0.173 & - & $0.222(0.135)$ & + & 0.281 & $-0.202(0.185)$ \\
\hline NWTD & - & 0.453 & - & $0.203(0.271)$ & + & 0.260 & - $0.259(0.262)$ \\
\hline RECINV & - & 0.120 & - & $0.010(0.340)$ & + & 0.551 & $-\quad 0.056(0.277)$ \\
\hline WCTA & + & 1.099 & + & $2.081(0.038)$ & + & 0.122 & $+1.663(0.188)$ \\
\hline TDTA & + & 0.793 & + & $0.595(0.552)$ & + & 0.245 & $-0.418(0.763)$ \\
\hline NISA & + & 0.126 & - & $0.073(0.719)$ & + & 0.005 & $-\quad 0.054(0.795)$ \\
\hline
\end{tabular}

\section{SAWC $+0.119+0.002(0.600)+0.094-0.020(0.470)$ \\ SHAREH $+0.573+0.021(0.008)-0.670+0.024(0.009)$} ( $\mathrm{P}$-values are given in parenthesis)

$$
\text { Eigenvalue }=0.069 \quad \text { Eigenvalue }=0.059
$$

2

Correlation $=0.254 \mathrm{X}^{2}=43.341 \quad$ Correlation $=0.235 \mathrm{X}^{2}=30.652$

Wilk's Lamda $=0.936$ Signif. $=0.000$ Wilk's lamda $=0.945$ Signif $=0.002$

$\mathrm{X}^{2}=27.438$ Wald test $=145.631 \mathrm{X}^{2}=18.249$ Wald test $=105.043$

Significance $=0.007 \quad$ Significance $=0.108$

N of observations: $\quad$ N of observations:

Total 996 Total 996

Valid 421 Selected cases included in the analysis 328

Table 6: Classification Table for GROUP (Percent Correct-Overall Index)

$\begin{array}{cc}\begin{array}{c}\text { Discriminant } \\ \text { Analysis }\end{array} & \text { Logit } \\ \text { Analysis }\end{array}$

One Yr-Before (All data)

$$
\begin{array}{cccc}
101(55.8) & 80(44.2) & 179 & 2(98.9) \\
13(31.0) & 29(69.0) & 41 & 1(2.4) \\
58.3 \% & & 80.7 \%
\end{array}
$$

One Yr-Before (Outliers excl.)

$$
\begin{array}{ccc}
72(52.6) & 65(47.4) & 1370(100.0) \\
8(24.2) & 25(75.8) & 330(0.0) \\
57.1 \% & 80.6 \%
\end{array}
$$

Two Yrs-Before (All data)

$$
\begin{array}{cc}
210(60.5) 137(39.5) & 3452(99.4) \\
22(29.7) 52(70.3) & 740(0.0) \\
62.2 \% & 81.9 \%
\end{array}
$$

Two Yrs-Before (Outliers excl.)

136(51.3) 129(48.7) $2641(99.6)$

16(25.4) $47(74.6) \quad 621(1.6)$

$55.8 \% \quad 80.8 \%$

As far as the correct classification is concerned, results presented in Table 5 justify the preference of logit against discriminant analysis. When all data (both years) are used, the percentage of correct classification is 81.9 percent with a logit model and only 62.2 percent with discriminant analysis. When outliers are excluded, the rates are 80.8 percent and 55.8 percent respectively. In a similar vein, when one year data are used results are 80.7 percent for logit and 58.3 percent for discriminant analysis. When outliers are excluded, the rates are 80.6 percent and 57.1 percent, respectively. It is worth noting that when assets size is included in the models, 
the picture changes tremendously when discriminant analysis is employed. When data for two years before the selection of auditors is employed, the rate of correct classification increases from 62.2 percent to 80.3 percent (from 55.8 percent to 80.8 percent with outliers excluded). When data for one year before the selection is used the rate increases from 58.3 percent to 82.1 percent (from 57.1 percent to 80.6 percent when outliers are excluded). As far as logit is concerned, using assets as a test variable with one year data, the correct classification changes from 80.7 percent to 85.2 percent (from 80.6 percent to 86.5 percent with outliers excluded), and with two years data the rate changes from 81.9 percent to 85.0 percent (from 80.8 percent to 85.4 percent with outliers excluded). Consequently, we offer prediction regarding the impact of assets size in clients' selection of auditors by a confirmation of Hypothesis 3. Based on the above empirical findings, it is suggested that the prediction model is an accurate forecast of the event of clients' selection of auditors.

\section{Conclusions and future research}

In an application of two dichotomous models that tested both the determinants of a dichotomous choice in a newly investigated area of research in a specific country and worldwide, the robustness of two widely used models indicates that the event of clients' selection of auditors can be predicted by a rate higher than $80.0 \%$ using a logit specification. The discriminating factors between the two groups of companies are mainly variables QATA (Quick Assets/Total Assets) when using one year data, and QATA(Quick Assets/Total Assets) and SHAREHOLD(level of shareholdings)(more than 5 percent)) when using two years data. The first has a negative relationship with the clients' decision for auditor's selection while the latter has a positive relationship.

As far as the hypotheses, we conclude the following:

The null hypothesis $(\mathrm{H} 0)$ (that there are significant differences between return on assets in the two groups of companies) is accepted which is inconsistent with a prior Greek study. We reject Hypothesis 1 which is consistent with the above mentioned study when outliers are excluded. Obviously, we reject Hypothesis 2 and, finally, we accept Hypothesis 3 which is consistent with the post 1992 liberalization of the Greek audit market. We offer prediction regarding the impact of assets size in clients' selection of auditors by a confirmation of Hypothesis 3 .

This application has taken place in listed companies. How the situation would be formed in case of not listed companies is a matter for future research since the business environment would be different. In terms of future research in this area, it is of interest that an expanding role in Audit Committees is now being played internationally by so-called ACs. These committees, which are typically formed by the board of directors of a firm to provide a higher level of expertise in negotiations between the firm and its auditor, have become more prominent in Greece in recent years (7.00 percent of ASE-listed firms in 2005, and 17.36 percent in 2007). The increasing role played by ACs presents new avenues for future research about clients' selection of auditors. In the meantime, the probable establishment of a regulatory body for the IFRS implementation and the forthcoming further liberalization of the auditing profession open new roads to investigate. Of utmost importance is to investigate the clients' selection of auditors in the new conditions where auditor rotation has been instituted by the EEC regulations. Finally, another venue for research is to examine the impact of audit and nonaudit fees disclosure on shareholders in making their investment and voting decisions.

\section{References}

[1] Abbott, L. J. and S. Parker. 2000. Auditor Selection and Audit Committee Characteristics. Auditing:A Journal of Practice and Theory:4767. http://dx.doi.org/10.2308/aud.2000.19.2.47

[2] Beattie, V. and S. Fearnley.1995.The Importance of Audit Firm Characteristics and the Drivers of Auditor Change in UK Listed Compa-
nies.Accounting and Business Research.25:227-239. http://dx.doi.org/10.1080/00014788.1995.9729912.

[3] Benston, G. J.1969.The Value of the SEC's Accounting Disclosure Requirements.The Accounting Review: 515-532.

[4] Brown, R. and A. Tarca.2005.A Commentary on Issues Relating to the Enforcement of International Accounting Reporting Standards in the EU.European Accounting Review.14.1:181-212 http://dx.doi.org/10.1080/0963818042000338997.

[5] Caramanis, C.1998.Assessing the Impact of Liberalisation on Auditor Behaviour: Accounting Research in Politically Charged Contexts.Accounting,Auditing and Accountability Journal.11.5:562-592. http://dx.doi.org/10.1108/09513579810239855.

[6] Chan, K. H.; K. Z. Lin and P. L. Mo.2006.A Political-Economic Analysis of Auditor Reporting and Auditor Switches.Review of Accounting Studies.11:21-48 http://dx.doi.org/10.1007/s11142-0066394-z.

[7] Chow, C. W.1982.The Demand of External Auditing: Size, Debt,and Ownership Influences. The Accounting Review: 272-291.

[8] Citron, D. and G. Manalis.2001.The International Firms as New Entrants to the Statutory Audit Market: An Empirical Analysis of Auditor Selection in Greece, 1993-1997.The European Accounting Review.10.3:439-459 http://dx.doi.org/10.1080/713764634.

[9] Cohen, J.; G. Krishnamoorthy and A.Wright.2010. Corporate Governance in the Post Sarbanes-Oxley Era: Auditors' Experiences. Contemporary Accounting Research.27.3:751-786. http://dx.doi.org/10.1111/i.1911-3846.2010.01026.x.

[10]Dao, M.; K.Raghunadan and D.Rama (2012),' Shareholder Voting on Auditor Selection,Audit Fees, and Audit Quality", The Accounting Review:87.1:149-171 http://dx.doi.org/10.2308/accr-10159.

[11]Deakin, E.1976.Distributions of Financial Accounting Ratios: Some Empirical Evidence. The Accounting Review: 90-96

[12]DeAngelo, L.1981.Auditor Size and Audit Quality.Journal of Accounting and Economics: 183-189. http://dx.doi.org/10.1016/01654101(81)90002-1.

[13] Eichenseher, J. W.1985.The Effects of Foreign Operations on Domestic Auditor Selection.Journal of Accounting, Auditing and Finance.8.3:195-209

[14]Ettredge, M.; P. B. Shane and D. B. Smith.1988.Audit Firm Size and the Association Between Reported Earnings and Security Returns. Auditing: A Journal of Practice and Theory.7.2:29-42.

[15]Firth, M. and A. Smith.1992.Selection of Auditor Firms by Companies in New Issue Market.Applied Economics. 24:247-255. http://dx.doi.org/10.1080/00036849200000123.

[16] Francis, R. J. and E. Wilson.1988.Auditor Changes: A Test of Theories Relating to Agency Cost and Auditor Differentiation. The Accounting Review: 663-682.

[17] Grant-Thornton.2006.Study on the Impact of IFRS Application on Greek Listed Companies in the Athens Stock Exchange (ASE). June.www.Grant-Thornton.gr (in Greek)

[18]Hodgdon, C.; R. H. Tondkar, A. Adhikari and D. W. Harless.2009.Compliance with International Financial Reporting Standards and Auditor Choice:New Evidence on the Importance of Statutory Audits.The International Journal of Accounting.44:33-55 http://dx.doi.org/10.1016/j.intacc.2008.12.003.

[19] Klein, B. and K. Leffer.1981.The Role of Market Forces in Assuring Contractual Performance.Journal of Political Economy.89:615-641. http://dx.doi.org/10.1086/260996.

[20] Krishnan,J. and Z.Ye (2005),'Why Some Companies Seek Shareholder Ratification on Auditor Selection',Accounting Horizons, 19,4,pp. 237-254 http://dx.doi.org/10.2308/acch.2005.19.4.237.

[21] Maddala, G. S.1991.A Perspective on the Use of Limited-Dependen and Qualitative Variables:Models in Accounting Research.The Accounting Review.66.4:788-807.

[22]Maggina,A. and A.Tsaklanganos(2011),'Predicting Audit Opinions:Evidence from the Athens Stock Exchange',. Journal of Applied Business Research.27,4:53-68

[23]Maijoor,S. and A.Vanstraelen(2012),' 'Research Opportunities in Auditing in the EU,Revisited",Auditing:A Journal of Practice and Theory,31,1,pp. 115-126 http://dx.doi.org/10.2308/ajpt-10209.

[24]Meyhew,B. and J.Pike(2004),' 'Does Investor Selection of Auditors Enhance Auditor Ïndependence?', The Accounting Review,79,3,pp. 797-822 http://dx.doi.org/10.2308/accr.2004.79.3.797.

[25]Palepu, K. G.1986.Predicting Take-Over Targets:A Methodological and Empirical Analysis.Journal of Accounting and Economics:3-35. http://dx.doi.org/10.1016/0165-4101(86)90008-X

[26] Raghunandan,K.(2003), 'Nonaudit Services and Shareholder Ratification of Auditors',Auditing:A Journal of Practice and Theory,22,1,pp. 155-163 http://dx.doi.org/10.2308/aud.2003.22.1.155. 
[27]Simmunic, D. A. and M. Stein.1987.Product Differentiation on Auditing:A Study of Auditor Choice in the Market for Unseasoned New Issues.Canadian Certified General Accountants' Research Foundation.

[28]So, J. C.1987.Some Empirical Evidence on the Outliers and NonNormal Distribution of Financial Ratios.Journal of Business Finance and Accounting.14.4:483-486 http://dx.doi.org/10.1111/j.1468 5957.1987.tb00108.x

[29]Spathis, C. T.2003.Audit Qualification,Firm Litigation,and Financial Information: An Empirical Analysis in Greece. International Journal of Auditing.7:71-85 http://dx.doi.org/10.1111/1099-1123.00006.

[30]Spathis, C. T., M. Doumpos and C. Zopounidis.2003. Using Clien Performance Measures to Identify Pre-Engagement Factors Associated with Qualifed Audit Reports in Greece.The International Journal of Accounting.38:267-284 http://dx.doi.org/10.1016/S00207063(03)00047-5.

[31] Titman, S. and B. Trueman.1986.Information Quality and the Valuation of New Issues. Journal of Accounting and Economics. 8:159-172. http://dx.doi.org/10.1016/0165-4101 (86)90016-9.

\section{Appendix I}

\begin{tabular}{lr}
\hline Auditing Firms in Greece and Their 2008 Market Share & \\
\hline PriceWaterhouse & $10.2 \%$ \\
KPMG & $4.4 \%$ \\
Ernst \& Young & $4.0 \%$ \\
Deloitte Touche & $2.9 \%$ \\
SOL (former Sworn-in Auditors) & $32.8 \%$ \\
Grant Thorton International & $15.3 \%$ \\
BDO & $15.0 \%$ \\
Baker & $6.9 \%$ \\
RFK & $3.3 \%$ \\
Moore Stevens & $1.8 \%$ \\
ORION & $0.7 \%$ \\
FRS Global & $0.7 \%$ \\
RPS & $0.4 \%$ \\
DFK International & $0.4 \%$ \\
Nexia Eurostatus & $0.4 \%$ \\
AXON & $0.4 \%$ \\
K.Sigalas & $0.4 \%$ \\
\hline
\end{tabular}

